\title{
An ethnobotanical survey of medicinal plants in Babungo, Northwest Region, Cameroon
}

\author{
David J Simbo
}

\begin{abstract}
Background: An ethnobotanical survey was undertaken to record information on medicinal plants from traditional medical practitioners in Babungo and to identify the medicinal plants used for treating diseases.

Methods: Traditional Medical Practitioners (TMP's) who were the main informants were interviewed using semistructured questionnaires and open-ended conversations. Field trips were made to the sites where TMP's harvest plants.

Results: The survey identified and recorded 107 plants species from 54 plant families, 98 genera used for treating diseases in Babungo. The Asteraceae was the most represented plant family while herbs made up 57\% of the total medicinal plants used. The leaf was the most commonly used plant part while concoction and decoction were the most common method of traditional drug preparation. Most medicinal plants (72\%) are harvested from the wild and $45 \%$ of these have other non medicinal uses. Knowledge of the use of plants as medicines remains mostly with the older generation with few youth showing an interest.
\end{abstract}

Conclusions: A divers number of plants species are used for treating different diseases in Babungo. In addition to their use as medicines, a large number of plants have other non medicinal uses. The youth should be encouraged to learn the traditional medicinal knowledge to preserve it from being lost with the older generation.

\section{Background}

Ethnobotany is the study of how modern and indigenous societies view and use plants [1]. The use of natural products with healing properties is as old as human civilization and for a long time, minerals, animal and plant products were the main sources of drugs [2]. The World Health Organization (WHO) defines traditional medicine as practices, knowledge and belief systems which uses minerals, plants and animal based remedies, spiritual therapies and exercises to prevent, treat and maintain well being [3]. According to the WHO, about $80 \%$ of the population of the world depends on traditional medicine, mostly herbal remedies, for their primary health care needs [4]. The African continent have a long history with the use of plants and in some African countries, up to $90 \%$ of the population rely on medicinal plants as a source of drugs [5]. A medicinal plant is any plant, which in one or more of its organs contains active ingredients which can be used for therapeutic

Correspondence: DavidJohngwoh.Simbo@ua.ac.be

Department of Bioscience Engineering Faculty of Science, University of Antwerp Groenenborgerlaan 1712020 Antwerp, Belgium purposes or contain foundation compounds that can be used for the synthesis of useful drugs [6]. The absence or inaccessibility of modern healthcare services, affordability, cultural acceptance and, under certain circumstances, effectiveness than their modern counterparts has caused a large percentage of the population to rely mostly on plant based traditional medicines for their primary health care needs. These factors and a growing interest in the use of natural products and folk medicine have resulted to an increase in the demand for medicinal plants [7]. This increase in demand puts a threat on natural resources. Knowledge on the use of medicinal plants is enormous but if this is not rapidly researched and recorded, indications are that it will be lost with succeeding generations [5].

An estimated $25 \%$ of prescription drugs and $11 \%$ of drugs considered essential by the WHO are derived from plants and a large number of synthetic drugs are obtained from precursor compounds originating from plants [2]. Therefore the documentation of the traditional therapeutic know-how could lead to the discovery of new drugs as well as contribute to the conservation, 
sustainable management and use of plant resources. Ethnobotanical investigations have been reported for parts of Cameroon [8-10] and parts of the adjacent Bamenda highlands [11] but no investigation has ever been carried out in Babungo. It is therefore necessary to carry out a survey to document the plants used for medicinal purposes in Babungo.

\section{Methods}

\section{Study site}

The study was carried out in Babungo, located in the Ngoketunjia division of the Northwest Region of the Republic of Cameroon. Babungo falls between latitude $6^{\circ} 01^{\prime}$ and $6^{\circ} 11^{\prime} \mathrm{N}$ and between longitudes $10^{\circ} 20^{\prime}$ and $10^{\circ} 29^{\prime} \mathrm{E}$ [12] as shown in figure 1 . The soil type is sandy clay ferruginous soil and the average altitude is $1200 \mathrm{~m}$ above sea level [13]. There are two seasons; the dry season from November to March and the rainy season from April to October. Annual precipitation is 2300 $\mathrm{mm}$. Situated in the Sudan savannah, it is mostly covered with Helictotrichon maitlandii C.E Hubbard, Andropogon gayanus Kunth and Pennisetum purpureum

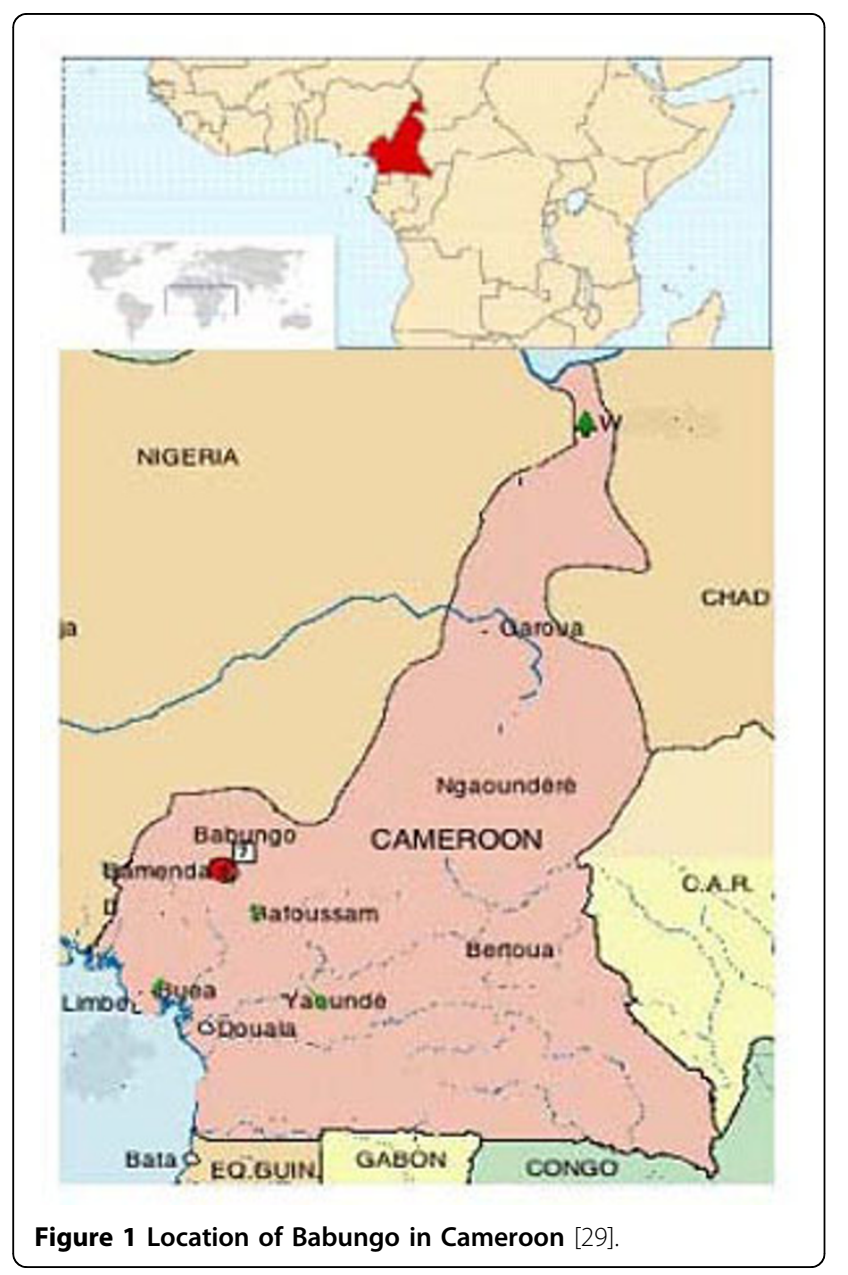

[13]. Common tree species include Cola spp., Spathodea campanulata P. Beauv., Markhamia lutea (Benth) K. Schum., Canarium schweinfurthii Engl. and Elaeis guinensis Jacq [12]. The population, of about 14,000 inhabitants, are mostly peasant farmers who grow corn for subsistence and rice and coffee as cash crops. Blacksmithing and wood carving are also common occupations.

\section{Data collection}

Traditional Medical Practitioners (TMP's) were the main informants in the survey. They were identified with the help of the traditional ruler and some of the elders of the tribe. A total of 17 TMP's were interviewed amongst whom 7 were literate. Their ages range from 28 to 70 years with more of them in the older side of the range. Most of the informants were men with only 4 females. After seeking their consent, the traditional medical practitioners were interviewed using semi-structure questionnaires and open-ended conversations. Trips were made to the sites where TMP's normally go to harvest plants and during such trips, there were discussions with the TMP's in addition to the interviews using the semi-structure questionnaires. The interviews and discussions were carried out in the local language since the author is a native speaker of the language. Data on the local names of the plants, the plant parts used, diseases treated by the plants, mode of usage and administration were collected in the field. Health conditions which were not recognized by the author were identified by the health professional at the health centre in Babungo. Plants recorded in the results were mentioned by at least two TMP's as treating the same disease in order to confirm its use. Fertile specimens of the plants were collected in the field using standard botanic methods [14] together with the TMP's. The collected specimens were identified at the National Herbarium in Yaoundé, Cameroon and voucher specimens were deposited at the herbarium of the Limbe Botanic Garden, Cameroon.

\section{Results}

A total of 107 medicinal plant species from 98 genera and 54 families used for treating about 55 health problems were identified in the survey (see additional file 1). The most represented plant family in the list of medicinal plants is the Asteraceae with $12.1 \%$ of the medicinal plants species followed by Lamiaceae and Poaceae with $5.6 \%$ each.

Herbs made up $57 \%$ of the total number of medicinal plants followed by trees (24\%), shrubs (15\%), and climbers making up the remaining $4 \%$. The leaves were the most commonly used plant part followed by the aerial parts of herbs $(8 \%)$ and then by the bark $(7 \%)$ of woody plants. The roots $(6 \%)$, the flowers $(5 \%)$, the fruits $(4 \%)$ 
and latex (4\%) are also used medicinally while the whole plant is the least used (3\%).

Many plants $(51.4 \%)$ have multiple medicinal uses and many diseases are treated using a combination of more than one plant (Additional file 1). For example venereal diseases are treated by oral administration of a concoction of the roots of Capsicum frustescens, Vernonia amygdalina, C. schweinfurthii and the bracts of Musa paradisciaca. For some species, the same part is used to treat different diseases. For example the leaves of Carica papaya are used for treating malaria and gastritis.

C. papaya, Eucalyptus spp., Mangifera indica and Psidium guajava do not have names in the local language and so their English names are used. Some plants from the Asteraceae family (Ageratum conyzoides, Crassocephalum rubens, Dichrocephalla integrifolia, Erygerum floribundus and Vernonia calvoana) are commonly called ndobovensi which translates to the devil's cigarette.

Decoctions were the most common method of preparation and most of the medicines are administered orally with topical administration in the case of skin diseases or wounds. The most commonly known and used plants are Aspilia africana to treat wounds, Celosia globosa to treat athlete's feet, Cymbopogon citratus for fevers and Ocimum gratissimum for stomachache.

Medicinal plants were harvested from the wild, from farms and fallows and some home gardens. From the list of medicinal plants (Additional file 1), 8.4\% are cultivated exclusively for medicinal purposes (table 1), 19.6\% are domesticated crops and fruits from farms, fallows or grown in compounds (table 2) and $72 \%$ are collected entirely from the wild. Forty five percent of medicinal plants (Additional file 1) have other non-medicinal uses as shown in table 3. For example wood from Bersama abyssinica, C. schweinfurthii, Cordia platythyrsa, Croton macrostachus are used for building houses, tool handles and furniture while Annanas comosus, C. papaya, Citrus

Table 1 Plants cultivated solely for their medicinal uses.

\begin{tabular}{ll}
\hline Scientific name & Family \\
\hline Aloe vera (L.) Burm.f. & Liliaceae \\
\hline $\begin{array}{ll}\text { Asystasia gangetica (L.) } \\
\text { T. Anders. }\end{array}$ & Acanthaceae \\
\hline Basella alba $\mathrm{L}$. & Basellaceae \\
\hline Cymbopogon citrates & Poaceae \\
(DC.) Stapf. & Acanthaceae \\
\hline $\begin{array}{l}\text { Eremomastax speciosa } \\
\text { (Hochst.) Cufod. }\end{array}$ & Lamiaceae \\
\hline Ocimum gratissimum L. & Rosaceae \\
\hline Prunus africana (Hook.f.) & \\
\hline Kalkman & Caesalpiniaceae \\
\hline Senna alata (L.) Roxb. & Apocynaceae \\
\hline Voacanga africana Stapf. &
\end{tabular}

Table 2 A list of domesticated crops and fruits used for medicinal purposes.

\begin{tabular}{|c|c|}
\hline Scientific name & Family \\
\hline $\begin{array}{l}\text { Aframomum melegueta } \\
\text { K. Schum }\end{array}$ & Zingiberaceae \\
\hline Allium sativum $\mathrm{L}$. & Alliaceae \\
\hline Amaranthus hybridus L. & Amaranthaceae \\
\hline Annanas comosus (L.) Merr. & Bromeliaceae \\
\hline Capsicum annuum L. & Solanaceae \\
\hline Carica papaya $\mathrm{L}$. & Caricaceae \\
\hline Citrus aurantium L. & Rutaceae \\
\hline Citrus limon (L.) Burm.f. & Rutaceae \\
\hline $\begin{array}{l}\text { Cola acuminata (P. Beauv.) } \\
\text { Schott \& Endl. }\end{array}$ & Sterculiaceae \\
\hline Elaeis guinensis Jacq. & Arecaceae \\
\hline Mangifera indica L. & Anacardiaceae \\
\hline Musa paradisiaca L. & Musaceae \\
\hline Musa sapientum L. & Musaceae \\
\hline Nicotiana tabacum $\mathrm{L}$. & Solanaceae \\
\hline Ocimum basilicum L. & Lamiaceae \\
\hline Psidium guajava $\mathrm{L}$. & Myrtaceae \\
\hline Raphia hookeri Man \& Wendl. & Arecaceae \\
\hline Ricinus communis $L$. & Euphorbiaceae \\
\hline $\begin{array}{l}\text { Sorghum bicolor (L.) } \\
\text { Moench. }\end{array}$ & Poaceae \\
\hline $\begin{array}{l}\text { Vernonia amygdalina } \\
\text { Delile }\end{array}$ & Asteraceae \\
\hline Zea mays $L$. & Poaceae \\
\hline
\end{tabular}

aurantium, $M$. indica and $P$. guajava are common edible fruits.

Prunus africana was reported by the TMP's to be extinct from the wild. A few stands of dead P. africana trees were seen during the field survey. Existing trees are found in private gardens and in some compounds.

Most of the TMP's were above 45 years old with only one less than 30 years old. Thus knowledge of the use of plants to treat diseases remains mostly with the older generation.

\section{Discussion}

More plants from the family Asteraceae are used for medicinal purposes compared to any other plant family in Babungo because they contain a wide range of biologically active compounds and also because being one of the largest families in the plant kingdom, a large number of plants belong to this family $[15,16]$. The popularity of herbs in traditional medicine has been linked to their higher likelihood of containing pharmacologically active compounds compared to woody plant forms [16]. This may explain why more than half the plants recorded in the survey are herbs. Babungo is located in the grassland 
Table 3 Non medicinal uses of medicinal plants in Babungo.

\begin{tabular}{|c|c|c|c|}
\hline Scientific name & Family & Local name & Use \\
\hline $\begin{array}{l}\text { Aframomum melegueta } \mathrm{K} \text {. } \\
\text { Schum. }\end{array}$ & Zingiberaceae & Iswo & Used for driving away evil spirits. \\
\hline $\begin{array}{l}\text { Afrostyrax kamerunensis } \\
\text { Perkins \& Gilg }\end{array}$ & Huaceae & Fulong & Used as a spice. \\
\hline Agave sisalana Perrine & Agavaceae & Nseng & Production of fibres. \\
\hline Allium sativum $\mathrm{L}$. & Alliaceae & Garlic & Used as a spice. \\
\hline Amaranthus hybridus L. & Amaranthaceae & Fih & Eaten as a leaf vegetable. \\
\hline Annanas comosus (L.) Merr. & Bromeliaceae & Pineapple & The fruits are edible. \\
\hline Bersama abyssinica Fresen. & Melianthaceae & Fuaveti & Timber used for construction. \\
\hline Bidens pilosa L. & Asteraceae & Shoctesuc & Whole plant is burn to repel insects. \\
\hline $\begin{array}{l}\text { Bryophylum pinnatum } \\
\text { (Lam.) Oken }\end{array}$ & Crassulaceae & Juteweh & The juice from the leaves is used to remove stains. \\
\hline Caladium spp. & Araceae & Lala & Ornamental plant. \\
\hline $\begin{array}{l}\text { Canarium schweinfurthii } \\
\text { Engl. }\end{array}$ & Burseraceae & Tibew & $\begin{array}{l}\text { The latex is burnt to drive away evil spirits. The fruits are edible and the wood is } \\
\text { used as timber. }\end{array}$ \\
\hline Capsicum annuum L. & Solanaceae & Nyanta & The fruits are added to food. \\
\hline Capsicum frutescens $\mathrm{L}$. & Solanaceae & Nyantafesucse & The fruits are added to food. \\
\hline Carica papaya L. & Caricaceae & Pawpaw & The fruits are edible. \\
\hline Citrus aurantium L. & Rutaceae & Orange & The fruits are edible. \\
\hline Citrus limon (L.) Burm.f. & Rutaceae & Lemon & The fruit juice is added to some herbal teas. \\
\hline $\begin{array}{l}\text { Cola acuminata (P. Beauv.) } \\
\text { Schott \& Endl. }\end{array}$ & Sterculiaceae & Ibi & The seeds are served to guest to chew. \\
\hline $\begin{array}{l}\text { Colocasia esculenta (L.) } \\
\text { Schott. }\end{array}$ & Araceae & Ndai & The tubers are edible. \\
\hline $\begin{array}{l}\text { Cordia platythyrsa } \\
\text { Barker }\end{array}$ & Boranginaceae & Ibokwing & The wood is used for carving. \\
\hline $\begin{array}{l}\text { Croton macrostachus } \\
\text { Hochst ex Delile }\end{array}$ & Euphorbiacea & Njang & The wood is used for carving, fuel wood and for tool handles. \\
\hline $\begin{array}{l}\text { Cymbopogon citratus (D.C) } \\
\text { Stapf. }\end{array}$ & Poaceae & Ghaishek & The leaves are used for tea. \\
\hline Elaeis guinensis Jacq. & Arecaceae & Iteh & $\begin{array}{l}\text { The fruits used for making palm oil and the kernels for palm kernel oil. Palm wine } \\
\text { is tapped from the tree. }\end{array}$ \\
\hline $\begin{array}{l}\text { Entada abyssinica Steud. ex } \\
\text { A. Rich. }\end{array}$ & Mimosaceae & Fundung & The leaves are used for fodder. \\
\hline $\begin{array}{l}\text { Eryngium foetidium (L.) } \\
\text { Urb. }\end{array}$ & Apiaceae & Bulung & The plant repels snakes. \\
\hline Eucalyptus spp. & Myrtaceae & 'Forest guide' & The wood is used for construction, furniture and for making xylophones. \\
\hline Ficus exasperata Vahl & Moraceae & Ngwase & The leaves are used to scrub and clean kitchen utensils. \\
\hline Ficus thonningii Blume & Moraceae & Ngung & Used for life fences. \\
\hline $\begin{array}{l}\text { Jateorhiza macrantha } \\
\text { (Hook.f.) Exell \& Mendonça }\end{array}$ & Menispermaceae & & The leaves are used as toilet tissue in the bush. \\
\hline $\begin{array}{l}\text { Kigelia africana (Lam.) } \\
\text { Benth. }\end{array}$ & Bignoniaceae & Thai & The wood is used for construction and tool handles. \\
\hline Lantana camara $\mathrm{L}$. & Verbenaceae & 'Flower' & Ornamental plant. \\
\hline Mangifera indica $\mathrm{L}$. & Anacardiaceae & 'Mango' & The fruit pulp is eaten. \\
\hline $\begin{array}{l}\text { Markhamia lutea (Benth.) } \\
\text { K.Schum ex Engl. }\end{array}$ & Bignoniaceae & $\begin{array}{l}\text { Bengtifua/ } \\
\text { Tibeng }\end{array}$ & Provides shade. The wood is used for tool handles and carving. \\
\hline Musa paradisiaca $\mathrm{L}$. & Musaceae & Yuck & The fruits are eaten. \\
\hline Musa sapientum L. & Musaceae & Nkwili & The ripe fruits are eaten. \\
\hline Nicotiana tabacum L. & Solanaceae & Ndobo & The dried leaves are smoked. \\
\hline Ocimum basilicum L. & Lamiaceae & Zwitefua & A decoction of the leaves is used to bath children who cry at night. \\
\hline
\end{tabular}


Table 3: Non medicinal uses of medicinal plants in Babungo. (Continued)

\begin{tabular}{|c|c|c|c|}
\hline Ocimum gratissimum $\mathrm{L}$. & Lamiaceae & Fulungfu & The plant serves as insect repellent. \\
\hline $\begin{array}{l}\text { Piliostigma thonningii } \\
\text { (Schum.) Milne-Redh. }\end{array}$ & Caesalpiniaceae & Bing & The wood is used for construction. \\
\hline $\begin{array}{l}\text { Polyscias fulva (Hiern.) } \\
\text { Harms }\end{array}$ & Araliaceae & Vai & The wood is used for making xylophones. \\
\hline $\begin{array}{l}\text { Prunus africana (Hook.f.) } \\
\text { Kalkman }\end{array}$ & Rosaceae & 'Kanda stick' & The wood is used for construction and for tool handles. \\
\hline Psidium guajava $\mathrm{L}$. & Myrtaceae & Guava & The fruit is edible. \\
\hline $\begin{array}{l}\text { Raphia hookeri G.Mann \& H. } \\
\text { Wendl. }\end{array}$ & Arecaceae & Kho & Sap from the palm is drunk as wine. \\
\hline Ricinus communis L. & Euphorbiaceae & Medjai & The seeds are used in the production of castor oil. \\
\hline $\begin{array}{l}\text { Sorghum bicolor (L.) } \\
\text { Moench }\end{array}$ & Poaceae & Saigini & The grains are edible. \\
\hline $\begin{array}{l}\text { Spathodea campanulata } \\
\text { P.Beauv. }\end{array}$ & Bignoniaceae & Tibaibai & The wood is used for firewood and for making drums. \\
\hline Trema orientalis (L.) Blume & Ulmaceae & Fai & The wood is used for building houses. \\
\hline Vernonia amygdalina Delile & Asteraceae & Ying & The leaves are edible. \\
\hline Voacanga Africana Stapf. & Apocynaceae & Thau & The seeds have a commercial Value. \\
\hline Zea mays $\mathrm{L}$. & Poaceae & Sai & The grains are the main staple food. \\
\hline
\end{tabular}

savannah which favours the growth of herbs. Most societies and cultures have a sound knowledge of the biodiversity in their environments as a result of long term experimentation and innovation [17]. This may explain the use of many herbs in the traditional medicinal practice in Babungo. Leaves of plants have been reported to accumulate, inulins, tannins and other alkaloids [18] which may be responsible for their medicinal properties, explaining its wide use. Other studies reported the leaves as the most widely used plant parts [[10,11], and [19]].

Aloe vera is used to treat malaria, gastritis, stomach ache, wounds and skin diseases, Spilanthes filicaulis is used to treat toothache, stomach ache, gastritis and malaria, Lactuca capensis is used to treat malaria, hypertension and gastritis. This may be because some plants contain many secondary metabolites which could have different pharmacological activities and consequently treat different diseases. The TMP's believe that combining more than one plant re-enforces the medicines, increasing their effectiveness. Similar findings have been reported in Ethiopia [20]. Pharmacological studies supported this believe [21]. However the same study reported that combining some drugs could have antagonistic effects.

A. africana has been found to contain phytochemicals which are capable of arresting wound bleeding, preventing the growth of wound contaminating microbes and accelerating wound healing [22]. Similar phytochemical analyses have been made for C. citratus [23] and O. gratissimum [24] and they were found to contain chemicals which relieve fevers and stomach ache respectively. This scientifically validates their common use for these purposes in Babungo.
The fact that many medicinal plants have other uses may lead to their over exploitation, threatening their continuous survival in the area. Not many medicinal plants were cultivated solely for their medicinal values. This is because most people will prefer to cultivate food or cash crops rather than medicinal plants since most medicinal plants are either not sold or sell at very low prices and therefore not profitable, providing very little incentives for their cultivation.

Some exotic species do not have names in the local language and were called by their English names. This is because these are recently introduced species in the area. In some cases, the names of plants in the local language were descriptive of some character of the plant; $S$. filicaulis called nyantanyui literally translating to God's pepper because of its pepper-like tasting flowers. The grouping of the some Asteraceae under one common name could reflect the local system of plant classification.

The use of the bark of $P$. africana in the local traditional medicine and exploitation for commercial purposes has resulted to the extinction of the species from the wild. The bark was harvested and sold to Plantecam, a company which exported the bark or its processed extracts to Europe for manufacture of drugs used to treat benign prostatic hyperplasia sold under the brand name "Tadenan" (France) or "Pygenil" (Italy) [25]. $P$ africana has been listed by the International Union for the Conservation of Nature (IUCN) on its redlist of threatened species [26] for which conservation action must be taken.

Many of the medicinal plants used in Babungo have been reported in other areas with similar or different 
uses; 12 species were found to be used in the Mount Cameroon area [9], 17 species are used in the neighbouring Fundong subdivion [11] and 19 species in Aguambu [10]. One species, Vernonia calvoana, has been cited as a new entrant in the list of medicinal plants in Cameroon [11]. Four species were listed in Kenya [27] while 3 and 13 species were documented in the mid-west and southeast of Ethiopia respectively [20,28]. The use of medicinal plants across cultures and wider geographic regions has been discussed as prove validating their medicinal properties [28]. The chemical composition of some of the plants reported in this study has been scientifically studied. The root of Rauvolfia vomitoria, used traditionally for high blood pressure, has been found to contain reserpine which lowers the blood pressure and slows down the heartbeat while the flowers of S. filicaulis were found to contain spilanthol a local anaesthetics [9]. The seeds if C. acuminate has been reported to contain $2.5 \%$ caffeine, which is known to stimulate the central nervous system [5]. This explains why cola nuts are chewed as a stimulant by the people of Babungo.

Most young people are not interested in traditional medical practice because it is less profitable compared to growing cash crops. The influence of western culture, rural-urban migration in search for better educational and job opportunities and the commonly held view by young people that traditional medicine is superstitious and something for the poor and uneducated may result to a loss of this rich and useful knowledge which has accumulated over several generations.

\section{Conclusions}

The survey shows that a large number of medicinal plants are used in Babungo for treating different ailments. The knowledge of the use of plants to treat diseases has been with the people for generations but has not been recorded. This knowledge remains mostly with the traditional medical practitioners who are mostly old people. Most of the medicinal plants are sourced from the wild. In addition to their medicinal uses, some of these plants have other uses. The local population should be educated on sustainable methods of harvesting plants to treat diseases today without compromising their availability for future use. The youth should also be encouraged to learn the traditional medicinal knowledge to preserve it from being lost with the older generation.

Additional file 1: Medicinal plants used in Babungo for treating different diseases. The additional file list botanical and local names of the plants, the plant part used, the use and the preparation and mode of administration.

Click here for file

[http://www.biomedcentral.com/content/supplementary/1746-4269-6-8S1.PDF ]

\section{Acknowledgements}

I wish to thank the Traditional Medical Practitioners in Babungo for serving as key informants for this study. Athanasia Mbah-Fongkimeh of the University of Buea, Cameroon is also acknowledged for reviewing the questionnaire and making suggestions. I am also grateful for the contribution made by Linda Koye, the health professional at the Babungo health centre, who identified some of the diseases. My thanks also go to Dr. Sylvestre Njomo Njako and Sebastiaan De Smedt of the University of Antwerp for reading through the manuscripts. I like to express my gratitude to two anonymous reviewers whose comments and positive criticisms helped to improve the manuscripts.

\section{Authors' contributions}

Being the sole author, DJS initiated the idea, developed the questionnaire, carried out the survey and wrote the article.

\section{Competing interests}

The author declares that they have no competing interests.

Received: 22 September 2009 Accepted: 15 February 2010 Published: 15 February 2010

\section{References}

1. Balick MJ, Cox PA: Plants, People, and Culture: The Science of Ethnobotany. Scientific American Library: New York 1996.

2. Rates SMK: Plants as a source of drugs. Toxicon 2001, 39:603-613.

3. WHO: Traditional medicine. Fact sheet No 1342003.

4. Muthu C, Ayyanar M, Raja N, Ignacimuthu S: Medicinal plants used be traditional healers in Kancheepuram District of Tamil Nadu, India. J Ethnobio Ethnomed 2006, 2:43.

5. Hostettmann K, Marston A, Ndjoko K, Wolfender J-L: The Potential of African Medicinal Plants as a Source of Drugs. Current Organic Chemistry 2000, 4:973-1010.

6. Sofowora A: Medicinal plants and traditional medicine in Africa. Spectrum books limited: Ibadan 1993.

7. Vulto AG, Smet PAGM: Drugs used in non-orthodox medicine. Meyler's side effects of drugs Elsevier: AmsterdamDukes MMG , 11 1988, 999-1005.

8. Thomas DW, Thomas JM, Bromley WA, Mbenkum FT: Korup Ethnobotany survey. Final report to the World Wide Fund for Nature Surrey: UK 1989.

9. Ndenecho EN: Herbalism and resources for the development of ethnopharmacology in Mount Cameroon region. Afr J Pharm Pharmacol 2009, 3(3):078-086.

10. Focho DA, Ndam WT, Fonge BA: Medicinal plants of Aguambu-Bamumbu in the Lebialem highlands, southwest province of Cameroon. Afr J Phrm Pharmacol 2009, 3(1):1-13.

11. Focho DA, Newuh MC, Anjah MG, Nwana FA, Ambo FB: Ethnobotanical survey of trees in Fundong, Northwest Region, Cameroon. J Ethnobiol Ethnomed 2009, 5:17.

12. MINEF: Annual report of activities carried out by the Divisional Section for Forestry, Ngokentunjia. Ministry of Environment and Forest 1999.

13. Ndenecho EN: Cropping Systems and Post-Cultivation Vegetation Successions: Agro-Ecosystems in Ndop, Cameroon. J Hum Ecol 2009, 27(1):27-33

14. Olorode O: Taxonomy of West African Flowering Plants. Longman: London 1984.

15. Heinrich M, Robles M, West JE, Ortiz de Montellano BR, Rodriguez E: Ethnopharmacology of Mexican Asteraceae (Compositae). Annual Review of Pharmacology and Toxicology 1998, 38:539-565.

16. Thomas E, Vandebroek I, Sanca S, Van Damme P: Cultural significance of medicinal plant families and species among the Quechua farmers in apillampampa, Bolivia. Journal of Ethnopharmacology 2009, 122:60-67.

17. Dovie BK, Witkowski ET, Shackleton CM: Knowledge of Plant Resource use Based on Location, Gender and Generation. Applied Geography 2008, 28:311-322.

18. Okoegwale EE, Omefezi JU: Some herbal preparations among the people of Isoko Clan of Delta State, Nigeria. J App/ Sc 2001, 4:2350-2371.

19. Signorini MA, Piredda M, Bruschi P: Plants and traditional knowledge: An ethnobotanical investigation on Monte Ortobene (Nuoro, Sardinia). J Ethnobiol Ethnomed 2009, 5:6. 
20. Flatie T, Gedif T, Asres K, Gebre-Mariam T: Ethnomedical survey of Berta ethnic group Assosa Zone, Benishangul-Gumuz regional state, mid-west Ethiopia. J Ethnobiol Ethnomed 2009, 5:14.

21. Chow KU, Nowak D, Boehrer S, Ruthardt M, Knau A, Hoelzer D, Mitrou PS, Weidmann E: Synergistic effects of chemotherapeutic drugs in lymphoma cells are associated with down-regulation of inhibitor of apoptosis proteins (IAPs), prostate-apoptosis-response-gene 4 (Par-4), death-associated protein (Daxx) and with enforced caspase activation. Biochemical Pharmacology 2003, 66:711-724.

22. Okoli CO, Akah PA, Okoli AS: Potentials of leaves of Aspilia africana (Compositae) in wound care: an experimental evaluation. BMC Complementary and Alternative Medicine 2007, 7:24.

23. Olaniyi AA, Sofowora EA, Oguntimehin BO: Phytochemical investigation of some Nigerian plants used against fevers. II. Cymbopogon citratus. Planta Med 1975, 28(2):186-189.

24. Akinyemi KO, Oladapo O, Okwara CE, Ibe CC, Fasure KA: Screening of crude extracts of six medicinal plants used in South-West Nigerian unorthodox medicine for anti-methicillin resistant Staphylococcus aureus activity. BMC Complementary and Alternative Medicine 2005, 5:6.

25. Cunningham AB, Mbenkum FT: Sustainability of harvesting of Prunus Africana bark: A Medicinal Plant in International Trade. People and Plants working paper 2 Paris: Unesco 1993.

26. IUCN 2009: IUCN Red list of Threatened Species. Version 2009.2 Downloaded on 05 December 2009. [http://www.iucnredlist.org].

27. Bussmann R: Ethnobotany of the Samburu of Mt. Nyiru, South Turkana, Kenya. J Ethnobiol Ethnomed 2006, 2:35.

28. Lelukal E, Kelbessa E, Bekele T, Yineger H: An ethnobotanical study of medicinal plants in Mana Angetu District, southeastern Ethiopia. J Ethnobiol Ethnomed 2008, 4:10.

29. Fonjong LN, Mbah FA: The Fortunes and Misfortunes of Women rice Producers in Ndop, Cameroon and the Implications for Gender Roles. Journal of International Women Studies 2007, 8(4):133-147.

doi:10.1186/1746-4269-6-8

Cite this article as: Simbo: An ethnobotanical survey of medicinal plants in Babungo, Northwest Region, Cameroon. Journal of Ethnobiology and Ethnomedicine 2010 6:8.

\section{Submit your next manuscript to BioMed Central and take full advantage of:}

- Convenient online submission

- Thorough peer review

- No space constraints or color figure charges

- Immediate publication on acceptance

- Inclusion in PubMed, CAS, Scopus and Google Scholar

- Research which is freely available for redistribution 